\title{
PROOF!
}

SEE JPCL 30 (2015), 44-62 for the final version.

\section{The discovery, nature, and implications of a Papiamentu text fragment from 1783}

\author{
Bart Jacobs and Marijke van der Wal \\ University of Konstanz / Leiden University
}

\begin{abstract}
In this paper, we discuss the recent discovery of four letters written in 1783, one of which is written fully in Papiamentu, the other three comprising Papiamentu fragments. The data in these constitute one of the earliest written attestations of Papiamentu. We first provide a brief overview of the earliest attestations of Papiamentu and then present the Letters as Loot research programme, to which we owe the discovery of the 1783 letters. Following this, the article discusses the contents of the letters and the socio-historical context in which they were written. To close, we discuss the value of this new source for Papiamentu studies.
\end{abstract}

Keywords: early (late-18th-century) Papiamentu, Letters as Loot, Curaçao, Dutch

\section{Early references to and written attestations of Papiamentu}

Controversial as the place of birth of Papiamentu may be, discussing whether the language developed in situ or was imported from elsewhere, scholars agree on particular historical-linguistic aspects, such as the view that the language established itself as a communication vehicle on Curaçao in the second half of the 17th century and had become the dominant speech and mother tongue among the slaves and freed slaves by the turn of the 18th century (e.g. Kouwenberg \& Muysken 1995: 205; Bartens 1996:274). These assumptions are supported by several testimonies. In 1704, for instance, the German Father Alexius Schabel mentioned in his travelogue that the 'slaves of Curaçao speak broken Spanish' (cf. e.g. van Wijk 1958: 169; Bartens 1996:248). A few decades later, in 1732, a Father Caysedo reported that, in addition to Spanish, Portuguese, and Dutch, the people of Curaçao spoke 'el idioma del país' ['the language of the country]' (in Hartog 1968: 157). A legal deposition of 1737 mentions the use of the 'creolse taal' ['creole language'] by Afro-Curaçaoans (Rupert 2012:214). 
The first explicit mention of the glossonym Papiamentu (or variants thereof) is found in a most interesting document dated 1747 and discussed in detail in Kramer (2008). The document describes the court hearing that took place in New Port (Rhode Island) in 1747, i.e. towards the end of the War of the Austrian Succession (1739-1748). ${ }^{1}$ The court hearing was held in order to shed light on the seizure in the same year of the Dutch ship the Jonge Johannes by an English privateer (cf. \$2). The English, exceptionally at peace with the Dutch at the time (cf. Table 3), had erroneously assumed the ship to belong to Spain, a misunderstanding that appears to have been created by the fact that members of the ship's crew spoke a language resembling Spanish. At the court hearing, a member of the ship's crew was able to convince the court that the ship was in fact sailing under the Dutch flag and that the language spoken on board the ship was not Spanish but Papiamentu. The relevant passage of the hearing is provided below (from Kramer 2008: 101):

Q(uestio)n: What Language did the People on board the Sloop Speak.

An(swer): Dutch, Spanish, and Poppemento, but chiefly Poppemento.

$\mathrm{Q}($ uestio)n: Whether they commonly talk Poppemento in Curaçao.

An(swer): Yes.

Q(uestio)n: Whether you have any knowledge of any Cocoa being sent home to Curaçao in another Vessel.

An(swer): No.

Q(uestio)n: Can you speak Dutch.

An(swer): No.

Subsequent references to the use on Curaçao of 'Papiamento', 'Papimento', 'Papiments', and 'Papiamentice' are found in reports and letters by an anonymous Venezuelan cleric (1768), the Venezuelan lieutenant Manuel Carrera (1795), the British co-governor William Carlyon Hughes(1802), governor Pierre J. Changuion (1805), and the Minorite priest Johannes Stöppel (1816) respectively (cf. Hartog 1968: 157; especially Rupert 2012:217, 241 and references therein). Table 1 summarizes the earliest references to Papiamentu that we know of.

1. This was principally a war between Austria and Prussia in which the English and the Dutch allied with the former while France and Spain sided with the latter. 
Table 1. The earliest references to Papiamentu ${ }^{2}$

\begin{tabular}{ll}
\hline Year & Context \\
\hline 1704 & Father Alexius Schabel: 'broken Spanish' \\
1732 & Father Agustín Caysedo: 'the language of the country' \\
1737 & Legal deposition: 'creolse taal' \\
1747 & Curaçaoan Sailer Torinio Lopes: 'Poppemento' \\
1768 & Anonymous report to archbishop of Caracas: 'Papiamento' \\
1795 & Venezuelan lieutenant Manuel Carrera (1795): 'Papiamento' \\
1802 & British co-governor William Carlyon Hughes: 'Papimento' \\
1805 & Governor Pierre J. Changuion: 'Papiments' \\
1816 & Minorite priest Johannes Stöppel: 'Papiamentice' \\
\hline
\end{tabular}

The first written attestation of Papiamentu dates from $1775 .{ }^{3}$ It concerns a love letter written in fluent Papiamentu by a Curaçaoan Sephardic Jew to his mistress. The letter has been the subject of articles such as Wood (1972) and Salomon (1982) (see also Kramer 2004:217-222). The second written attestation is a short (60word) conversation between two female slaves recorded in the court testimony of Semuel Costa Andrade in 1776 and is transcribed in Maduro (1971) and Maurer (1998). Up until very recently, an Aruban court procedural document from 1803 (transcribed e.g. in Martinus 1996) was considered the third earliest attestation, but Van der Wal (2011) recently discovered four letters from an earlier date, i.e. 1783, one of which is written fully in Papiamentu, the other three comprising Papiamentu fragments. Table 2 lists the earliest written attestations of Papiamentu.

The newly discovered letters are part of the Letters as Loot corpus, compiled at the University of Leiden.

2. Rupert (2012:215) furthermore found references to the use on Curaçao of 'creole, 'black speech', and 'language of the country' in archival records from the 1770s through to the early 19th century. In the course of the 19th century the glossonym Papiamentu (Papiamento in Aruba), became well established.

3. Arguably, and at least according to Martinus (1996:9), the very first piece of data to be considered written Papiamentu is the name of a Sephardic Jewish ship, Awa pasa harina, registered in 1767. The name closely resembles the modern-day Papiamentu idiomatic expression awa a pasa hariña with the meaning of 'bad times' (lit. 'water has surpassed the flour'). 
Table 2. The earliest written attestations of Papiamentu ${ }^{4}$

\begin{tabular}{llll}
\hline Year & Text type & Word count & Author \\
\hline 1775 & private letter & ca. 150 words & Sephardic Jew \\
1776 & dialogue & ca. 60 words & Sephardic Jew \\
1783 & private letters & $\begin{array}{l}\text { ca. } 80 \text { words }+ \\
\text { ca. } 25 \text { words }\end{array}$ & Anna Elisabeth Schermer-Charje \\
& & Dutch \\
1790 & eyewitness report 15 words & unknown \\
1803 & legal petition & ca. 300 words & unknown \\
1833 & Catholic catechism & ca. 1500 words & Father Niewindt \\
\hline
\end{tabular}

\section{The Letters as Loot research programme}

The Letters as Loot research programme, conducted at Leiden University, concentrates on a recently rediscovered collection of Dutch documents from the second half of the 17th to the early 19th centuries, comprising over 38,000 letters, both commercial and private ones (cf. Van Gelder 2006). ${ }^{6}$ These documents were confiscated during the frequent warfare of England and the Netherlands in the past, when no fewer than four Anglo-Dutch Wars (cf. Table 4) were fought, apart from the American War of Independence and the Napoleonic period in which both countries stood on opposite sides.

4. Following Niewindt's catechism (1833/2002), the output of evangelical texts (catechisms, gospels) written in Papiamentu increased rapidly, culminating in a full Papiamentu Bible translation in the early 20th century (Eybers 1916). In addition, from the mid-19th century onwards, grammatical sketches and word lists in and of Papiamentu began to appear, while some newspapers were publishing articles in Papiamentu as early as in the late 19th century. It is also pertinent to briefly draw attention here to a handful of short Papiamentu folkloric songs that could be heard in Coro, Venezuela, well into the 20th century. Although written down only in the late-20th century, the songs actually trace back to the mid- to late-18th century, when significant numbers of Curaçaoan runaway slaves settled in Coro (see Lipski 2005: 192 and references therein).

5. This concerns a single sentence found in the eyewitness report of a street fight kindly brought to our attention by Han Jordaan.

6. The research programme Letters as loot. Towards a non-standard view on the history of Dutch was initiated by Marijke van der Wal (Leiden) and is funded by The Netherlands Organisation for Scientific Research (NWO); cf. also http: //www.brievenalsbuit.nl (English version). 
Table 3. Chronology of Anglo-Dutch Wars in the seventeenth and eighteenth centuries ${ }^{7}$

\begin{tabular}{ll}
\hline 1st Anglo-Dutch War & $1652-1654$ \\
2nd Anglo-Dutch War & $1665-1667$ \\
3rd Anglo-Dutch War & $1672-1674$ \\
4th Anglo-Dutch War \& American War of Independence & $1776-1784$ \\
Napoleonic period & $1793-1813^{7}$ \\
\hline
\end{tabular}

This warfare involved privateering, a longstanding legitimate activity, performed by all seafaring European countries and regulated by strict rules. When private ships (privateers) authorized by a country's government, attacked and seized cargo from enemy ships, the conquered ship and all its cargo were considered as loot for the privateer, if rules had been followed scrupulously (Van Gelder 2006: 10). In England, it was the High Court of Admiralty (HCA) that had to establish whether the current procedures had been properly followed. In order to be able to decide whether the ship was a so-called lawful prize, all the papers on board, both commercial and private, were confiscated. After the legal procedure, the confiscated papers stayed in the High Court of Admiralty's Archives, gathering dust for centuries; nowadays, they are stocked in a thousand boxes in the British National Archives (Kew, UK). To fully appreciate the huge number of letters in these boxes it is important to note that in very many cases the ships' cargo contained a lot more mail than the crew's own correspondence. Ships often took mailbags on board and thus functioned as mail carriers between the Netherlands and remote regions such as the Caribbean and East India (Van Gelder 2006: 10-15). The largest share (62\%) of the more than 38,000 Dutch letters, sent from the Netherlands all over the globe and vice versa, was found to be confiscated on ships to and from the Caribbean, many of them sailing in the period of the 4th Anglo-Dutch war (Van Gelder 2006:31). Thus we find letters, for instance, to and from St Eustatius, Curaçao, Surinam, Essequibo (present Guyana) and Demarara (present Guyana).

Among the whole collection it is the number of about 15,000 private letters that are priceless material for scholars from various disciplines. These private letters report, for instance, on singular events such the Great Hurricane of 1780 in the Caribbean and more generally on daily life, hardship, joy and sorrow at home and abroad. For historical linguists in particular, interested in the scarcely documented daily language of the past, their value cannot easily be overestimated. As the letters were written to and by spouses, children, relatives and friends, they

7. In 1807, Curaçao fell into English hands, but the WIC restored Dutch rule in 1815. This English period of occupation enabled English borrowings to enter the Papiamentu language including core vocabulary items such as the frequently used adverbs bèk and $d j i s<$ Eng. back and just. Wood (1971) is concerned with English linguistic influences in Papiamentu. 
represent the so-called language of proximity, characterized by informality and a degree of orality (cf. Koch \& Oesterreicher 1985). The relative proximity to authentic speech or the 'speech-like' nature of such private letters has been stressed by among others Nevalainen \& Raumolin-Brunberg (2003:29) and Elspass (2012:162). What makes the Dutch letters even more attractive and most suitable for historical sociolinguistic research is that the writers were people from all social ranks, men and women alike. Thus the letters are a highly valuable linguistic source that allows us to fill gaps in the history of Dutch (cf. Van der Wal, Rutten \& Simons 2012). Although in our Letters as Loot research programme we mainly focus on phenomena and issues related to the history of Dutch, we regularly come across surprising finds that are relevant for the history of other languages. ${ }^{8}$ Such an intriguing find is a late-eighteenth-century Papiamentu letter and three Dutch letters with Papiamentu words and phrases, all dating from 1783. They originate from the network of the Charje family, living on the island of Curaçao in the last decades of the 18th century.

\section{Socio-historical context of the Papiamentu letters}

The Letters as Loot corpus contains ten letters, dating from January and February 1781 and January 1783, that were written by members of the Dutch Charje family. ${ }^{9}$ February 1781, from Curaçao, both Jacob Charje (married to Anna Sophie Charje) and his eldest son Pieter Andries write to 'sister' and aunt Dorothea Boufet in Amsterdam. ${ }^{10}$ At the beginning of 1783 , Pieter Andries once more writes to his aunt and Jacob Charje writes two letters to his son-in-law Dirk Cornelis Schermer in Rotterdam. Dirk Cornelis, born 22 April 1759, started his career as a sailor as constable's assistent on the East India Company ship Diana at the age of sixteen. ${ }^{11}$ From his letter of January 1781 written to his brother-in-law Jan Spruit in

8. One example is an 18th-century letter that includes a Frisian text. Cf. www.brievenalsbuit.nl under 'Monthly letters' the letter of March/April 2012.

9. Dirk Schermer's letter to his brother-in-law Jan Spruijt is located in box HCA 30-326 of the National Archives (Kew, UK). The two letters to Dorothea Boufet, dating februari 1781, are to be found in HCA 30-365 (the letter by Jacob Charje) and HCA 30-366 (the one by Pieter Andries Charje). The other letters, all dating from January 1783, are located in HCA 30-370.

10. Dorothea Boufet most probably was Jacob Charje's sister-in-law or a stepsister. According to the marriage registers of the town of Amsterdam, her maiden name was Ho(o)genbos when she married Jan Boufet on 15 July 1757.

11. This and other genealogical information is derived from the Letters as Loot database which comprises the results of archival research and of searches in databases such as VOC opvarenden. 
Rotterdam, we know that he by then had obtained the attractive job of mate on the warship De Arend that lay in the roadstead of St Eustatius with destination Curaçao. On Curaçao he must have met Jacob Charje's daughter, Anna Elisabeth, to whom he is married by January 1783, when she writes two letters (one of which contains a short, annexed letter) to her husband Dirk and one to her mother-inlaw, widow Elisabeth Schermer-Pipardus, who both stay in Rotterdam. At the same time mother Anna Sophie Charje sends a letter to her son-in-law Dirk which, apart from the signature, is not an autograph, but was written by her daughter Anna Elisabeth. ${ }^{12}$

Table 4. The Charje family

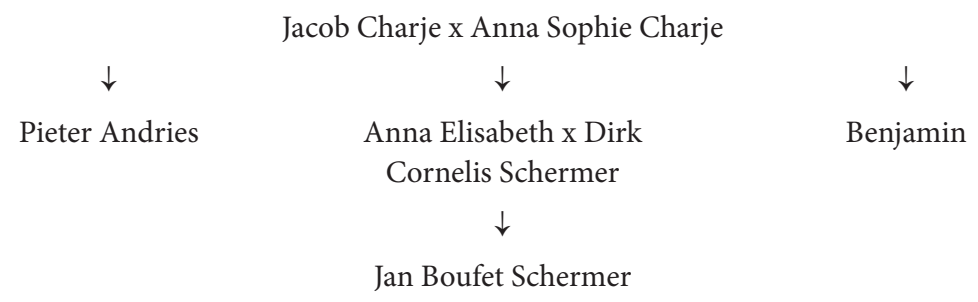

The letters comprise some information about the social rank and the occupations of the family members. As a mate, and later captain, Dirk Cornelis Schermer belongs to our category high middle class. ${ }^{13}$ Jacob Charje's occupation is not quite clear from the letters. We may assume that he was a merchant, as he apologizes for not being able to sell goods for Dirk Cornelis due to his old age and illness. His wife explains that he can neither help with financing, because he spent much money on a country-seat. As Dutch 'colonizers' we may assume that the family belonged to the upper class of 18th-century Curaçao.

One may notice that Charje is not a Dutch family name and neither is Boufet. In the 18th century, the name of Boufet regularly occurs in the DTB registers (baptism, marriage and burial registers) of the town of Amsterdam, the name of Charje (Charie, Charié) only occasionally. The families may have descended from French Huguenots, many of which fled France in the 16th and 17th centuries not rarely seeking refuge in the Netherlands. Moreover, although we lack concrete numbers, it is historically documented that some French Huguenot families who had

12. For the problem of determining whether a letter is autographic or not we refer to Nobels \& Van der Wal (2012) and Van der Wal, Rutten \& Simons (2012: 143-146).

13. In our research we distinguish four social ranks, i.e. high — high middle - low middle low, mainly founded upon the writers' occupation and/or the occupation of family members. This division closely follows the one historians use (Frijhoff \& Spies 1999: 190-191), the most important exception being that the so-called patriciate is not represented in our corpus. 
previously lived in the Netherlands resettled on Curaçao in the 18th century. ${ }^{14}$ Clearly, Dorothea Boufet and her husband, captain Jan Boufet lived in Amsterdam. From the letters by Pieter Andries Charje, it also appears beyond any doubt that the Charjes had Dutch roots and had lived in the Netherlands prior to moving to Curaçao: Pieter Andries refers to an earlier stay in the Netherlands and expresses his wish to return to Patria. In the remainder of this article we will therefore consider the Charje family as representatives of the Dutch Curaçaoan upper class.

Comparing the letters sent by members of the Charje family, the three letters by Anna Elisabeth stand out remarkably. Much to our surprise, one of them contains as appendix another, brief letter fully in Papiamentu, addressed to Dirk Cornelis Schermer and sent by his newly-born son Jan Boufet Schermer. Furthermore, these three Dutch letters comprise Papiamentu words and phrases which do not occur either in mother Anna Sophie's letter (written by Anna Elisabeth, as noted previously) or in any of the other letters.

We give a brief impression of the letter that Anna Elisabeth wrote to her mother-in-law, Elisabeth-Schermer-Pipardus, widow with five under-age children when her husband Jan Schermer died (7 June 1775). Anna Elisabeth had not met her yet, but she knew the art of tactful and cordial letter writing when addressing her mother-in-law who was surprised by the unexpected marriage of her son Dirk. She explains that it was neither her own intention to marry so soon, but that 'her beloved Dirk did not want to wait so long. It clearly is a love marriage: Anna Elisabeth is fond of her husband to whom she repeatedly refers as mijn lieve man 'my dear husband' (one instance) and mijn (lieve) doesje 'my sweetheart' (three instances). Her mother-in-law may have guessed what the Papiamentu doesje meant. ${ }^{15}$

Whereas there was only one Papiamentu hypocorism in the letter to her mother-in-law, in her two letters to her husband Anna Elisabeth employs a more elaborate repertoire of Papiamentu words and phrases. On 6 January her letter begins with Mie Alma dousje \& Mi Courasson 'my soul, darling \& my heart' and ends with Mi alma dousje die mi Courasson 'my soul, darling of my heart' and on 8 January her letter both begins and ends with Mi dousje, Mi bieda \& Mi courasson 'my darling, my life \& my heart'. In the longest letter, dating from 6 January, two other instances of (mij) bieda lief 'my beloved life' and four instances of doesje

14. A case in point is Jean Rodier, a French Huguenot who became the governor of the Netherlands Antilles in 1758 (Kunst 1983).

15. The word doesje, nowadays $d u s h i /$ 'du $\mathrm{i} /$, is etymologically derived from either Spanish dulce or Portuguese doce 'sweet'. The use of dushi in Anna Elisabeth's letter as well as in the written Papiamentu fragments from 1775 and 1776 suggests this was a common term of endearment in late-18th-century Papiamentu. It continues to be so in present-day Papiamentu. 
occur alongside Dutch names of endearment such as mijn hartje lief (twice), mijn lief, mijn zieltje lief (twice), mijn tweede ziel, mijn (lieve) ziel(tje) (eight instances). Dirk must have understood them, whether they were Dutch or Papiamentu, just as he must have grasped the meaning of the New Year's greeting at the end of the letter: boon anja nobo 'happy new year.' There is even a strong indication that he was familiar with Papiamentu beyond a few words and phrases. Why would Anna Elisabeth otherwise include a letter almost fully written in Papiamentu and express her affection towards Dirk in that same language?

The Papiamentu letter is presented as being written by Dirk's son Jan Boufet Schermer who was born during his absence and who must have been a few months old at the time of writing. He undoubtedly was named after uncle Jan Boufet at mother's side and grandfather Jan Schermer at father's side. Dit heeft uw Jantje geschreven 'Your Jantje has written this/ This has been written by your Jantje' features at the end of the Papiamentu letter in Anna Elisabeth's handwriting. The child's letter offers us a new 80-words long Papiamentu text from the late eighteenth century.

\section{Jan Boufet's Papiamentu letter}

We present the letter as follows: the first line contains the original Papiamentu text; the second line provides the present-day Papiamentu equivalent (using the Curaçao/Bonaire orthography), followed by the English translation in the third line.

1 Mi papa bieda die mi Courasson

Mi papa bida di mi kurason

'My father, life of my heart'

2 bieni prees toe seeka bo joego doesje

bini lihé seka bo yu dushi

'come to your sweet son quickly'

3 mi mama ta warda boo, mie jora toer dieja pa mie papa mi mama ta warda bo, mi [ta] yora tur dia pa mi papa 'my mother awaits you, I cry all day for my father'

4 Coemda Mie groot mama pa mie ie mie tante nan toer Kumindá mi wela pa mi i mi tanta nan tur 'greet my grandmother and all my aunts for me'

5 papa doesje treese oen boenieta son breer pa boo jantje papa dushi trese un bunita sombré pa bo Jantje 'Dear father, bring a nice hat for your Jantje' 
6 adjoos mie papa bieda die mi Courasson ayó mi papa, bida di mi kurason

'Goodbye my father, life of my heart'

7 djoos naa boo saloer pa mie i pa mie mama dios (du)na bo salú pa mi i pa mi mama 'may God give you health for me and for my mother'

8 mie groot mama ta manda koemenda boo moetje moetje mi wela ta manda kumindá bo muchu muchu 'my grandmother sends you lots of greetings'

9 mie ta bo joego Doe[s]je toena mortoo mi ta bo yu dushi te na morto 'I am your sweet son until death do us part'

10 Dit heeft uw Jantje geschreeven, nogmals adjoos vart wel 'Your Jantje has written this, goodbye once more [and] fare well.'

\section{Value of the letter for Papiamentu studies}

\subsection{Socio-linguistic implications}

The four letters, and particularly the Papiamentu fragments contained in them, allow us to draw some conclusions regarding the linguistic profile of the writer, Anna Elisabeth, and her husband Dirk Schermer. Anna Elisabeth must have been a comfortable speaker of Papiamentu — she may well have been a fluent Dutch-Papiamentu bilingual. ${ }^{16}$ Although the text is short, evidence of her command of the language is found, for instance, in the use of features that are typical of 'native' Papiamentu, such as verbal serialization (manda kumindá send-greet 'send greetings', line 8), reduplication (moetje moetje <much-much > 'very much', line 8), and the reduction of duna 'give' to naa (line 7) which is typical of (rapidly) spoken Papiamentu.

The fact that the Dutch Curaçaoan Anna Elisabeth was fluent in Papiamentu and used it in letters to her husband is socio-linguistically and historically salient for several (partially overlapping) reasons:

a. Whereas it was well-known (owing to the private letter from 1775) that Papiamentu had become the main communication vehicle among the Curaçaoan Sephardim by the second half of the 18th century, up to date we had no such empirical information on the role and diffusion of Papiamentu among the Dutch Curaçaoan upper class in that early period. Anna Elisabeth's letters suggest that

16. Christel Monsanto (Curaçao), who found various documents concerning the Charje family in Curaçaoan archives, kindly confirmed that Anna Elisabeth was born 11 August 1763 at Curaçao. She also suggested the importance of local yaya's 'nannies' which ties in with Rupert (2012:235). 
it had indeed diffused among the Dutch segment of the Curaçaoan upper class in the course of the 18th century.

b. Father G.B. Bosch, who visited Curaçao in the 1820s, wrote down his experiences in a 1829 travelogue. Amongst other things, Bosch (1829:212) suggests that the creole was initially more prevalent among women than among men: 'op Curaçao ( ... ) is een Spaansch patois, papiemento genaamd, de taal, die de Negers en gekleurden, die de kinderen der blanke inwoners en een groot gedeelte van het schoone geslacht bij voorkeur onder elkander spreken' ['on Curaçao, a Spanish patois, called Papiemento, is the preferred language among the Negroes and coloureds, the children of the white inhabitants, and a large part of the fair sex']. With particular respect to Curaçao and Jamaica, Rupert (2012:235) also posits a correlation between gender and creole language acquisition: 'European women who lived in the colonies frequently picked up creole languages faster than the men, at least in part owing to their close association with domestic servants and their children's contact with slave children and nannies.' Anna Elisabeth's letters provide a unique confirmation that this socio-linguistic state of affairs indeed applied to late-18th-century Curaçao. ${ }^{17}$

c. From the beginnings of the slave trade on Curaçao in the 1650 s and the subsequent creolization of the island's society, the West India Company's settlement policies aimed at maintaining a strict socio-cultural division between whites and the Afro-Curaçaoans. For instance, slaves were not allowed to become members of the Protestant church ${ }^{18}$ and the use of Papiamentu was officially prohibited on plantations and schools (Hartog 1968: 148; Fouse 2002:138). Anna Elisabeth addressing her husband in Papiamentu, however, suggests that the West India Company's prescriptions had only limited impact on the socio-cultural reality. Apparently, there was no way of preventing Papiamentu from making its way into the daily life of the white upper class. In fact, the letters compel us to conclude that the Dutch Anna Elisabeth had a surprisingly positive attitude towards Papiamentu: only then can we account for the fact that she used Papiamentu in private letters to her husband and even chose Papiamentu terms of endearment to refer to him in the letter addressed to her Dutch mother-in-law.

17. Hartog's (1968: 158) assertion that 'About 1825, this idiom [Papiamentu] was spoken by all coloured persons, and among the whites particularly by the ladies' is probably based on Bosch' travel account.

18. This state of affairs was fully exploited by the Venezuelan Catholic missionaries who visited Curaçao regularly, baptizing the incoming slaves. As a result, in the first half of the 18th century, Curaçao's slave society had become predominantly Catholic, rather than Protestant or Jewish (Klooster 1998:291; cf. also Hartog 1968: 178), compelling the Dutch West India Company to officially allow Catholicism on the ABC islands in the 1730s (Israel \& Schwartz 2007: 29). 
d. As mentioned previously, Anna Elisabeth's husband Dirk Cornelis Schermer must at the very least have had a basic knowledge of Papiamentu, even though he had been on Curaçao only for rather brief periods of layover. Being a sailor, he may have had his first encounters with Papiamentu on board ships of the Dutch West and East India Companies. The case of the Jonge Johannes discussed in $\$ 1$ suggests that Papiamentu indeed was not uncommon on board ships of the West India Company, though this remains questionable for the East India Company which was not involved in the Caribbean."

\subsection{Linguistic observations}

From a strictly linguistic point of view, the 1783 Papiamentu text reaffirms an important conclusion drawn previously by other authors on the basis of the 1775 and 1803 Papiamentu texts, namely that late-18th-century Papiamentu does not differ significantly from modern-day Papiamentu and, thus, that the grammar of the language had become quite stable at a relatively early date (see Wood 1972; cf. Kramer 2008:99). Exceptions to the continuity between early and modern-day Papiamentu in Anna Elisabeth's letter are limited to vocabulary items such as joego 'child, son, daughter', coemda 'to greet', and presto 'quick(ly)'. In the transition from early to modern-day Papiamentu, joego ( $<$ Sp. hijo) has been reduced to $y u$, the short form coemda has been abandoned in favour of the trisyllabic form $\mathrm{ku}$ mindá (indeed, the continuation of, or merger with, the form koemenda found in line 8 ), and prestoe ( $<$ Sp./Port. presto) has been replaced by synonyms such as lihé.

As far as the morphosyntax is concerned, the letter and sentences are too short to allow any far-reaching analyses, though we may at least point at the use of the third person plural pronoun nan as a postnominal pluralizer in line (4), the verbal serialization manda koemenda in line (8), and the polyfunctionality of $t a$ as a preverbal imperfective aspect marker in line (3) and a copula 'be' in line (9), all features characteristic of present-day Papiamentu. ${ }^{19}$

At a phonological level, we see that several sound changes that characterize modern-day Papiamentu had already (largely) been completed by the time of writing:

a. The words toer (modern Pap. tur < Port. tudo 'all') and saloer (modern Pap. salú < Sp. salud 'health' ( $\neq$ Port. saúde)) exemplify the change of etymological (i.e. Spanish or Portuguese) -/d/ or -/dV/ to modern-day Pap. -/r/ and often even -/Ø/. Similar developments can be seen in the transitions from Port. metade Sp. mitad

19. An anonymous reviewer rightly pointed out that, synchronically, it is incorrect to analyze ta as a polyfunctional morpheme: when used as a preverbal aspect marker, $t a$ always has a high tone; when used as a copula, $t a$ has polar tone. 
'half' to Pap. mitá mitar, from Sp./Port. medida 'measure' to Pap. midí, or Port. pode '[3sG.Pres.] be able' > Pap. por.

b. The verb trese, derived from Port. trazer ( $\neq$ Sp. traer), shows vowel harmony and the devoicing of the etymological /z/, processes that are typical of the older layers of the Papiamentu vocabulary (cf. Jacobs 2012a:Chapter 1).

c. The word anja 'year' (written <aña> in modern-day Papiamentu following Spanish spelling) is one of several basic vocabulary items that have undergone the change from etymological /o/ to /a/. Compare, for instance, Pap. bisiña 'neighbour', biña 'wine' and kurpa 'body', from Port. vizinho, vinho and corpo.

d. An interesting case of sandhi is found in the reduction of duna 'give' to naa (line 7). This reduction is still typical of (rapidly) spoken Papiamentu at present.

e. The aphaeresis and syncope of unstressed syllables of plurisyllabic words, typical of Papiamentu (e.g. Merka < Sp./Port. América), is reflected in bisyllabic Coemda (line 4), which occurs side by side with trisyllabic koemenda (line 8), both meaning 'to greet, salute' and derived from Sp./Port. encomendar (whose primary meaning is not 'to greet' but 'to commend'). Present-day Papiamentu to our knowledge only has preserved the trisyllabic variant kumindá 'greet', but similar variation is found in the present-day Papiamentu pair lanta and lamantá, both derived from Sp./Port. levantar. In this latter case, the pair was preserved probably due to the fact that the variants have developed a subtly different meaning: lanta 'to stand up', lamantá 'to revolt'.

In the domain of the vocabulary, apart from the fact that the letter gives us a better idea of the time-depth of certain lexical and lexico-semantic particularities of present-day Papiamentu (such as kumindá 'to greet', dushi 'sweetheart'), an interesting fact is the presence in the text of several Lusitanisms:

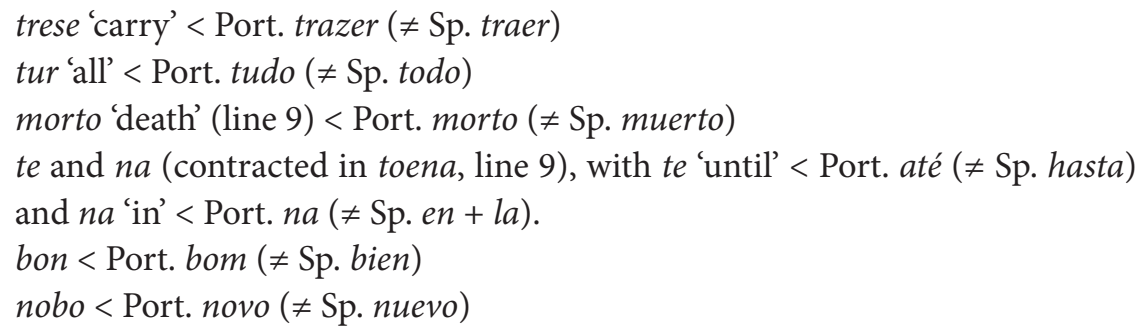

These Lusitanisms, found also in present-day Papiamentu, are revealing in the context of the much debated origins of Papiamentu, and more precisely of its Portuguese elements. Their presence in Anna Elisabeth's repertoire is evidence that they were firmly integrated also in the 'Dutch' variety of Papiamentu at an early date. It is implied, for instance, that the many Portuguese-derived items in the basic vocabulary of Papiamentu cannot be attributed to Curaçao's Sephardic Jewish community (pace Sanchez 2009: 835). Rather, Anna Elisabeth's linguistic heritage 
suggests that these Lusitanisms were part of the original Papiamentu grammar irrespective of any Curaçaoan Sephardic linguistic input. This, in turn, is in line with the hypothesis (to which we subscribe; cf. footnote 21) that Papiamentu was imported from elsewhere as an originally Portuguese-based creole and was subsequently (partially) relexified towards Spanish.

It should be noted, on the other hand, that the letter does not contain any Lusitanisms that are not also found in present-day Papiamentu and the same holds for the 1775 and 1776 samples. In other words, the relative proportion of Spanishto-Portuguese vocabulary in earlier forms of Papiamentu was roughly equal to what it is today. ${ }^{20}$ In discussing the 1775 Papiamentu letter, Wood (1972) already drew attention to this fact and (like others after him) interpreted this as evidence against the hypothesis that Papiamentu is a relexified descendant of a previously Portuguese-based pidgin or creole. ${ }^{21}$ If that hypothesis were correct, Wood argued, we would certainly expect to find additional (viz. not yet relexified) Portuguese vocabulary items in these early written attestations. Jacobs (2012b), however, argues against Wood, by noting that he erroneously assumed relexification to be a gradual process, whereas, in fact, most established cases of relexification have been shown to occur in the space of time of a single generation or less (i.e. typically no more than two to three decades). Under that premise, the pronounced Spanish character of the Papiamentu vocabulary in written attestations of the late-18th century is merely predictable: if Papiamentu was brought to Curaçao in the second half of the 17th century, relexification of its originally Portuguese vocabulary may well have been completed already by the turn of the 18 th century.

20. Words of Spanish origin in the letter include, for instance, Pap. bini, joego, jora, adjoos, saloer, moetje are derived from Sp. venir, hijo, llorar, adios, salud, mucho rather than from Port. vir, filho, chorar, adeus, saúde, muito. Many other words are of indecisive Spanish/Portuguese origin (e.g. Pap. $t a<$ Sp./Port. estar' to be').

21. This view of the origins of Papiamentu found broad support in the heyday of the so-called monogenesis framework, in which practically all creoles worldwide (be they French-, English-, Spanish-, Dutch-, or Portuguese-based) were said to descend from a common Portuguese-based proto-variety. Supporters of monogenesis models quite consistently put Papiamentu forward as a prime example of the diffusion and subsequent relexification of the alleged Portuguese-based proto-variety. At present, very few (if any) linguists still subscribe to creole monogenesis, but the specific view that Papiamentu is genetically related to the Portuguese-based creole of the Cape Verde Islands has received renewed attention particularly in the works of Martinus (1996), Quint (2000), and Jacobs (2009, 2012a), and is increasingly finding resonance in the literature (e.g. Clements 2012; McWhorter 2012). 


\section{Final remarks}

Tracing the linguistic diversity of the past, various types of, more or less scarce, sources are available, both speech-based such as recorded court testimonies and speech-like such as private letters. ${ }^{22}$ Both types of sources deliver the earliest Papiamentu text samples: a court testimony and a private letter, both by Curaçaoan Sephardic Jews. By the private letters discussed in the present paper, our knowledge of late-18th-century Papiamentu is further extended. The Papiamentu letter by Anna Elisabeth shows us, amongst other things, that Papiamentu had spread among, and become socially acceptable in, the Dutch upper class of Curaçao at a remarkably early date.

We may often wonder how people in the past communicated in various circumstances abroad. Anna Elisabeth's letters provide us with a view on the multilingual late-eighteenth-century society of Curaçao and on the function of Papiamentu for Dutch-Curaçaoan writers and their addressees. As she is the only individual of the family network who writes in Papiamentu, we may assume that the gender difference noticed for the 1820s by Bosch existed earlier in the 1780s. Her husband, however, must also have had a reasonable passive command of Papiamentu in order to be able to understand the remarkable letter from his son. What remains a bit of a mystery, however, is the precise function of the Papiamentu letter in the Dutch correspondence between spouses. Are the expression of longing and the transfer of greetings in Papiamentu an example of 'Spielerei' that was appreciated by husband Dirk Schermer? Whatever its function was, the letter figures as a lively and precious early Papiamentu fragment from the past.

Received: 9/28/12

Revised: $2 / 21 / 13$

Accepted: $2 / 21 / 13$

\section{References}

Bartens, Angela. 1996. Die iberoromanisch-basierten Kreolsprachen. Frankfurt am Main: Peter Lang.

Bosch, Gerardus-Balthasar \& Leonard Eduard Bosch. 1829. Reizen in West-Indië 1. Utrecht: Van der Monde.

22. Cf. Culpeper \& Kytö (2010:17) who distinguish three categories of speech related texts, i.e. speech-based, speech-like and speech-purposed (such as plays), each of which has own characteristics, advantages and disadvantages for research. 
Clements, Clancy J. 2012. The Spanish-based creoles. In José Ignacio Hualde, Antxon Olarrea \& Erin O'Rourke (eds.), The handbook of Hispanic linguistics, 27-46. Oxford: Wiley Blackwell. DOI: 10.1002/9781118228098.ch2

Culpeper, Jonathan \& Merja Kytö. 2010. Early modern English dialogues: Spoken interaction as writing. Cambridge: Cambridge University Press.

Elspass, Stephan. 2012. The use of private letters and diaries in Sociolinguistic investigation. In Hernández-Campoy \& Conde-Silvestre (eds), The handbook of historical sociolinguistics. 156-169. DOI: 10.1002/9781118257227.ch9

Eybers, G. J. 1916. E testament Nobo di nos Señor y Salbador Jesus Christo: Fielmente traduci segun e texto original. Amsterdam: Nederlands Bijbelgenootschap.

Fouse, Gary C. 2002. The story of Papiamentu. A study in slavery and language. Lanham: University Press of America.

Frijhoff, Willem \& Marijke Spies. 1999. 1650: Bevochten eendracht. The Hague: Sdu Uitgevers.

van Gelder, Roelof. 2006. Sailing letters. Verslag van een inventariserend onderzoek naar Nederlandse brieven in het archief van het High Court of Admiralty in The National Archives in Kew, Groot-Brittannië. Den Haag: Koninklijke Bibliotheek.

Hartog, Johan. 1968. Curaçao, from colonial dependence to autonomy. Aruba: De Wit.

Hernández-Campoy, Juan Manuel \& Juan Camilo Conde-Silvestre (eds.). 2012. The handbook of historical sociolinguistics. Chichester: Wiley-Blackwell. DOI: 10.1002/9781118257227

Israel, Jonathan \& Stuart B. Schwartz. 2007. The expansion of tolerance: Religion in Dutch Brazil (1624-1654). Amsterdam: Amsterdam University Press.

Jacobs, Bart. 2009. The upper Guinea origins of Papiamentu: Linguistic and historical evidence. Diachronica 26(3). 319-379. DOI: 10.1075/dia.26.3.02jac

Jacobs, Bart. 2012a. Origins of a Creole: The history of Papiamentu and its African ties. Berlin: Walter de Gruyter. DOI: 10.1515/9781614511076

Jacobs, Bart. 2012b. Embedding Papiamentu in the mixed language debate. Journal of Historical Linguistics 2(1). 52-82. DOI: 10.1075/jhl.2.1.05jac

Klooster, Willem. 1998. Illicit riches. Dutch trade in the Caribbean, 1648-1795. Leiden: KITLV Press.

Koch, Peter \& Wulf Oesterreicher. 1985. Sprache der Nähe - Sprache der Distanz. Mündlichkeit und Schriftlichkeit im Spannungsfeld von Sprachtheorie undSprachgeschichte. Romanistisches Jahrbuch 36. 15-43.

Kouwenberg, Silvia \& Pieter Muysken. 1995. Papiamento. In Jacques Arends, Pieter Muysken \& Norval Smith (eds.), Pidgins and creoles: An introduction, 205-218. Amsterdam: John Benjamins. DOI: 10.1075/cll.15.23kou

Kramer, Johannes. 2004. Die iberoromanische Kreolsprache Papiamento. Hamburg: Helmut Buske.

Kramer, Johannes. 2008. Die früheste Erwähnung und das früheste Wörterbuch des Papiamento. Romanistik in Geschichte und Gegenwart 14(1). 99-114.

Kunst, Antonie Johannes Marie. 1983. Jean Rodier, Fransman, hugenoot en Gouverneur van de 'eilanden van Curaçao'. In R. O. L. Palm, E. H. J. Martis, \& Ernest Cohen Henriquez (eds.), Miscellanea iuridica antiliana, 71-88. Leiden: Societas Iuridica Antilliana.

Lipski, John M. 2005. A history of AfroHispanic language: Five centuries, five continents. New York: Cambridge University Press. DOI: 10.1017/CBO9780511627811

Maduro, Antoine J. 1971. Bon papiamentu (i un appendix interesante). Curaçao: author's edition. 
Martinus, Efraim Frank. 1996. The kiss of a slave: Papiamentu's West-African connections. Amsterdam: Universiteit van Amsterdam dissertation.

Maurer, Philippe 1998. El papiamentu de Curazao. In Matthias Perl \& Armin Schwegler (eds.), América Negra: panorámica actual de los estudios lingüísticos sobre variedades hispanas, portuguesas y criollas, 139-217. Frankfurt am Main:Vervuert.

McWhorter, John. 2012. The nature of argument: Is the creole exceptionalism hypothesis dead? Journal of Pidgin and Creole Languages 27(2). 377-387. DOI: 10.1075/jpcl.27.2.07mcw

Nevalainen, Terttu \& Helena Raumolin-Brunberg. 2003. Historical sociolinguistics: Language change in Tudor and Stuart England. London: Pearson Education.

Niewindt, Martinus Joannes. [1833]2002. PrefectoApostulico di Curaçao na Cristian di su Mision. Bloemendaal: Libri Antilliani.

Nobels, Judith \& Marijke van der Wal. 2012. Linking words to writers: Building a reliable corpus for historical sociolinguistic research. In Nils Langer, Steffan Davies, \& Wim Vandenbussche (eds.), Language and history, linguistics and historiography: Interdisciplinary approaches, 343-361. Bern: Peter Lang.

Quint, Nicolas. 2000. Grammaire de la Langue Cap-Verdienne. Paris: L'Harmattan.

Rupert, Linda. 2012. Creolization and contraband. Curaçao in the early modern Atlantic world. Athens/London: The University of Georgia Press.

Salomon, H. P. 1982. The earliest known document in Papiamentu contextually reconsidered. Neophilologus 66. 367-376. DOI: 10.1007/BF01998981

Sanchez, Tara. 2009. Papiamentu. In Keith Brown \& Sarah Ogilvie (eds.), Concise encyclopedia of languages of the world, 835-836. Oxford: Elsevier.

van der Wal, Marijke. 2011. 'Mie alma dousje \& mi courasson'. Creools tussen Curaçao en Rotterdam. In Daer wij ul hoogelijck voor bedancken. Brieven belicht voor Wikiscripta Neerlandica, 31-37. Leiden: Brieven als Buit.

van der Wal, Marijke, Gijsbert Rutten \& Tanja Simons. 2012. Letters as loot. Confiscated letters filling major gaps in the history of Dutch. In Marina Dossena \& Gabriella Del Lungo Camiciotti (eds.), Letter writing in late modern Europe, 139-161. Amsterdam: John Benjamins. DOI: 10.1075/pbns.218.09wal

van Wijk, Henri. 1958. Orígenes y evolución del Papiamentu. Neophilologus 42. 169-182. DOI: 10.1007/BF01511371

Wood, Richard E. 1971. The English loanwords in Papiamentu. Nieuwe West-Indische Gids 48. 173-189. DOI: $10.1163 / 22134360-90002217$

Wood, Richard E. 1972. New light on the origins of Papiamentu: An eighteenth-century letter. Neophilologus 56. 18-30. DOI: 10.1007/BF01740494

\section{Online sources:}

www.brievenalsbuit.nl 


\section{Appendix}
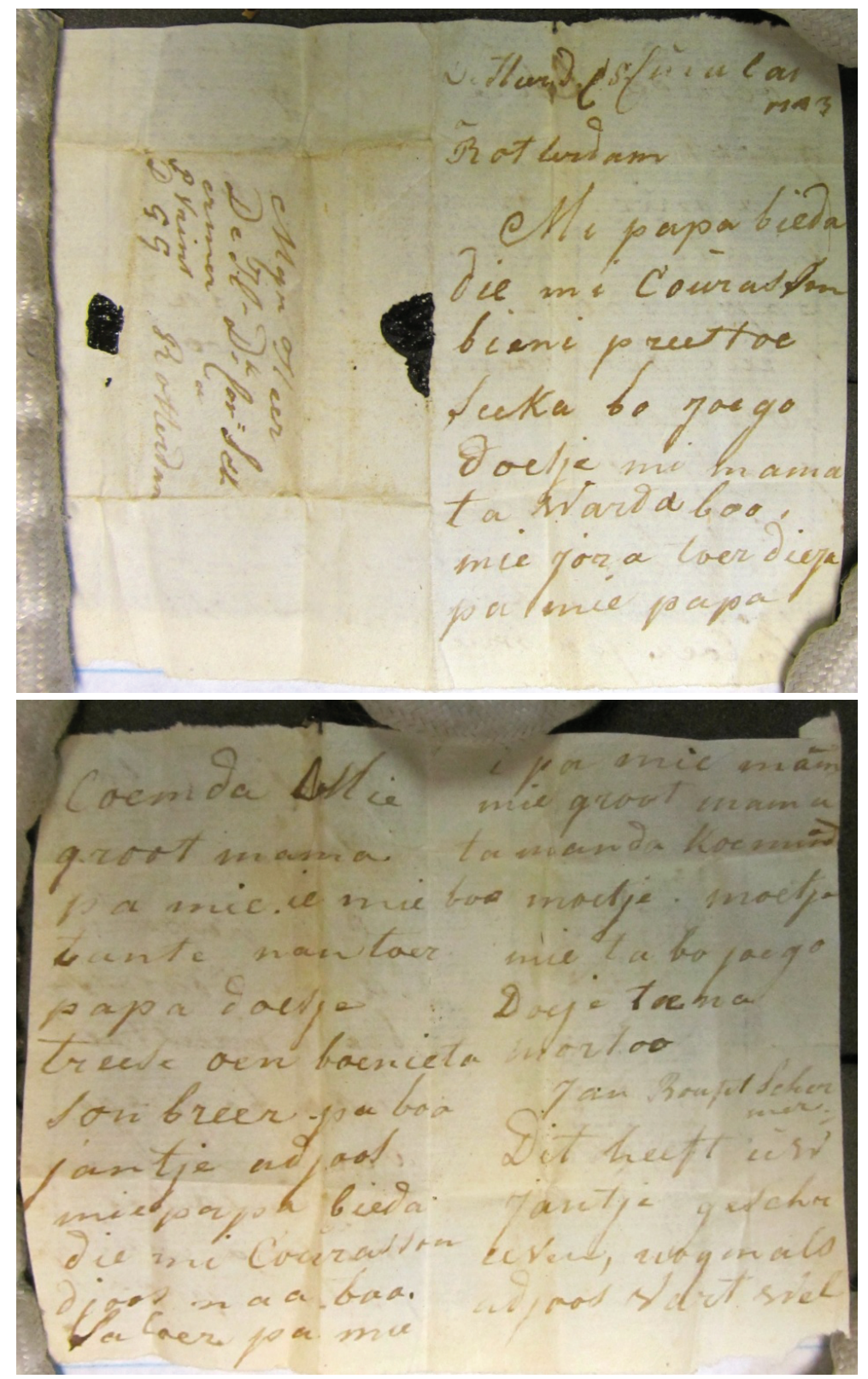

Jan Boufet's Papiamentu letter. National Archives (Kew, UK), HCA30-370, pictures taken by the Letters as Loot/ Brieven als Buit-project, Leiden University. 


\section{Author's addresses}

Bart Jacobs

University of Konstanz

Department of Romance Linguistics Faculteit der Geesteswetenschappen

Fach D 185

78457 Konstanz

bartjacobs3@googlemail.com
Marijke van der Wal

Leiden University

Witte Singel-complex

P.N. van Eyckhof 1

2311 BV Leiden

m.j.van.der.wal@hum.leidenuniv.nl 